\title{
The Role of The University of the West Indies Mona Libraries in HIV/AIDS Information Access and Dissemination
}

\author{
S Harris
}

\begin{abstract}
The recommendations for controlling HIV/AIDS, whether prescriptive or descriptive, underscore the value of information: its translation into knowledge, and knowledge into behaviour. Thus, accessing, evaluating, disseminating and applying authoritative, credible and scholarly information on HIV/AIDS are critical elements in the control of this pandemic in the Web 2.0 era. The University of the West Indies (UWI) Mona libraries have embraced this information role. This article provides insights into three of the information initiatives implemented by the UWI Mona libraries in this important capacity. In this regard, it also provides ideas for other West Indian information units and enhances communication on access to information products and services, albeit incrementally, in an important area of health services for the West Indies.
\end{abstract}

Keywords: Dissemination, HIV/AIDS, information access, knowledge

\section{EI Papel de las Bibliotecas de la Universidad de West Indies de Mona en VIH/SIDA Acceso a la Información y Difusión}

\author{
S Harris
}

\begin{abstract}
RESUMEN
Las recomendaciones para el control del VIH/SIDA, ya sean preceptivas o descriptivas, subrayan el valor de la información, en cuanto esta se traduce en conocimientos, en tanto que los conocimientos se traducen a su vez en conducta. Por lo tanto, el acceder, evaluar, difundir y aplicar información proveniente de fuentes autorizadas, fidedignas y académicas sobre el VIH/SIDA, son elementos críticos en el control de esta pandemia en la era Web 2.0. Las bibliotecas de la Universidad de West Indies (UWI) en el campus de Mona han hecho suyas este rol de la información. Este artículo ofrece un panorama de tres de las iniciativas de información implementadas por las bibliotecas de UWI Mona en esta importante capacidad. En este sentido, también proporciona ideas para otros centros de información en las Antillas, y mejora la comunicación para el acceso a productos y servicios de información - si bien de forma gradual - en un área importante de servicios de salud para las Antillas.
\end{abstract}

Palabras claves: Difusión, VIH/SIDA, acceso a la información, conocimiento

West Indian Med J 2013; 62 (4): 346

\section{INTRODUCTION}

The University of the West Indies (UWI) Mona Campus has an enrolment of approximately 11000 students and offers various programmes at the undergraduate, graduate and post-

From: Science Branch Library, The University of the West Indies, Kingston 7, Jamaica, West Indies.

Correspondence: Dr S Harris, Science Branch Library, The University of the West Indies, Kingston 7, Jamaica, West Indies. E-mail: sasekea.harris@ uwimona.edu.jm graduate levels in Humanities and Education, Medicine, Law, Social Sciences and Science and Technology. The UWI Mona libraries serve as the information hub for these offerings by providing vital material in support of teaching, learning and research. The importance of credible health-related information, literacy and technology skills and services in the reduction of HIV/AIDS cannot be overstated. The struggle between cultural views on sex and relationship vis à vis translating authoritative and scholarly information into knowledge and ultimately behaviour has implications for the control of 
this pandemic. The UWI Mona libraries play a particularly valuable role through their provision of access to critical information products and services which assist in furthering the understanding of HIV/AIDS.

This article is organized in three sections: the first section highlights the recommendations in the literature for information units and the role they should play in controlling HIV/AIDS and the second section looks in particular at how the initiatives of UWI Mona libraries underscore some of these recommendations. Accordingly, this second section looks at three initiatives implemented by the Mona libraries, namely: (a) how the UWI Mona libraries organize HIV/AIDS information for access and dissemination, (b) the use of Web 2.0 products in providing information access and dissemination and (c) the focus on information literacy as a contribution to HIV/AIDS control. The recommendations, conclusions and references constitute the final section (section three).

\section{The literature}

Regarding the role that libraries can play in the control of HIV/AIDS, the literature highlights the need to use information communication technologies (ICTs), the need to partner, to share information, to network and to facilitate information literacy. Albright and Kawooya (1) as well as Ghosh (2) point out the need for libraries to use ICTs and to partner with other organizations already involved in dissemination and education activities. Within the Web 2.0 era, the use of ICTs would be particularly relevant. However, this should not be without consideration for those who do not have access to or lack technology skills. Dube (3) and UNAIDS (4) also underline the need to share information and resources and the need to network. Given the perennial financial challenges which many libraries experience and the constant need for budget rationalization, this is a useful recommendation as it provides the opportunity to increase access to resources on HIV/AIDS. Dube's (3) work underscores the importance of information management and its communication. There is the tacit suggestion that libraries can do more with respect to how information is organized for access and dissemination. The literature also places accent on the importance of Internet information which infers a role for libraries. According to Gilmour (5), Internet health information is rated highly by users and is used to compensate for gaps in health information provided by health professionals. $\mathrm{He}$ adds, "Internet health information varies in terms of quality and readability" (5). This brings into focus the need for libraries to extend the provision of their quality information products and services over the Internet. Further, given the variation in quality, there is the intimation that libraries need to equip users with the skills to evaluate information on the Internet. Ghosh's (2) recommendation to libraries to transform their reading rooms into information/ knowledge centres where people, crippled with illiteracy or limited education, can find value underscores this point.
Further, it emphasizes the need for libraries to play a greater role in information literacy so that users can both find the information and the value in what is accessed.

\section{Information organization}

The UWI Mona libraries use the Library of Congress (LC) classification system to organize the resources on HIV/AIDS. Almost all information on HIV/AIDS is located within the following sections on the physical or electronic library shelves:

RA644.A25 HIV/AIDS and Public Health

RC607 HIV/AIDS and Internal Medicine

RG580.A44 HIV/AIDS and Pregnancy

RJ387.A25 HIV/AIDS and Children

LB3418.A35 HIV/AIDS and School Hygiene, Health

Services and Diseases

K3575.A43 HIV/AIDS and General Law

The UWI Mona libraries therefore provide access to information on HIV/AIDS in a structured, reliable and predictable manner. Thus, a user who has knowledge of this system knows exactly where to find information on HIV/ AIDS in any of the Mona libraries. For users who are not aware of this system, the UWI Mona catalogue "UWIlinC" guides users to these resources through simple keyword or author/title search.

According to Albright and Kawooya, "the role of libraries in disseminating HIV/AIDS information is strongest when libraries establish partnerships with other organizations already involved in dissemination and educational activities" (1). The use of Anglo American Cataloguing Rules (AACR2) and Machine-Readable Cataloging (MARC) bibliographic standards allows Mona libraries to share bibliographic resources on HIV/AIDS globally. The Mona libraries' use of Online Computer Library Center's (OCLC) Worldcat, which is a global catalogue shared by member libraries worldwide, allows UWI to showcase and share with other member libraries globally their bibliographic resources on HIV/AIDS generally and in particular those with emphasis on the West Indies. These libraries can import UWI Mona libraries' bibliographic records thereby reducing the time they spend cataloguing information on HIV/AIDS. This has the effect of getting HIV/AIDS information to users faster. According to Furrie, "if a library were to develop a "home-grown" system that did not use MARC records, it would not be taking advantage of an industry-wide standard whose primary purpose is to foster communication of information" (6). The Mona libraries also share these resources on the national level through the Jamaica Libraries and Information Network (JAMLIN), Scientific and Technical Information Network (STIN) and The University of the West Indies Mona Information Network (UWIMINET). Therefore, the Mona libraries organize HIV/AIDS information with the view to providing uniformed and reliable access as well as global reach. 


\section{Web 2.0 products}

Albright and Kawooya (1) recommend that libraries utilize ICTs for sharing digital materials to be effective in national HIV/AIDS campaigns. The Mona libraries have made a significant investment in building a collection of quality and scholarly resources in the form of electronic databases which provide remote access to books and full-text peer-reviewed articles from high impact journals on HIV/AIDS. Users can also access some of these journal articles on HIV/AIDS through smartphones. According to Dube (3), more research needs to be conducted and communicated within individual institutions and the sector as a whole. Consistent with this, the Mona libraries harvest and input data into Mona Online Research Database (MORD), which is a collection of research done by faculty, with useful research - published and unpublished by faculty - on HIV/AIDS as it relates to the West Indies in particular and the rest of the world. Additionally, through the use of twitter, users can follow the medical branch library's postings on HIV/AIDS and other medical related topics. Further, the provision of "Ask Mona", which is a virtual reference service accessible through the library's homepage, facilitates queries on accessing HIV/AIDS information resources. The medical and other librarians are assigned time slots between 10 am and 10 pm weekdays; during this period, users can have live chats with librarians. If a particular session requires the input of medical librarians, who might not be scheduled at that particular time, the query is forwarded for their attention. The provision of this solution has been a valuable contribution and in this respect the UWI Mona libraries are pioneers in Jamaica. While the provision of these services is consistent with the Web 2.0 era, the Mona libraries acknowledge that there are users without reliable access to technology and lacking the skills to use these online resources. The Mona libraries therefore maintain a viable collection of print resources on HIV/AIDS. This includes: books, theses, manuscripts, classroom resource materials and newspaper articles. In addition to this, the Mona libraries provide training, which is discussed in the ensuing section.

\section{Information literacy}

As previously indicated, Gilmour notes that Internet health information is rated highly by users and is used to compensate for gaps in health information provided by health professionals. He adds that "Internet health information varies in terms of quality and readability" (5). Similarly, studies such as Griffiths and Brophy (7), Fast and Campbell (8), Salisbury et al and Coombs (10) reveal that users often choose Google and Google Scholar over library databases. Notwithstanding this, these studies also indicate that library databases have a higher score for providing scholarly information as opposed to these search engines. In this regard, it is critical to ensure that health workers, health students in particular and users in general are equipped with the skills to evaluate Internet information. It also becomes more of an imperative for libraries to train users in the use of library databases as these provide more scholarly information. This is particularly important as "increasingly, nurses and other health professionals will need to assist patients and families locate and evaluate reliable, relevant and current health information on the Internet" (5). The UWI Mona libraries have established an entire department, the Mona Information Literacy Unit (MILU) which has training as its focus. Through this unit, the Mona libraries train future doctors, nurses and students in general on how to conduct effective research, how to use the library's databases and how to evaluate information on the Internet so that they can support the varying needs of their patients and to facilitate effective intervention. To enable a wider reach, training is embedded in a number of undergraduate and postgraduate courses; however, open sessions are also done as well as specially requested sessions whether individually or as a group. In this respect, the Mona libraries mobilize the young, the educated and healthcare workers to reduce the spread of HIV/AIDS. Gilmour provides support for this approach pointing out that "health literacy is necessary to develop the knowledge required to make informed choices and to access health services in a timely manner" (5).

\section{RECOMMENDATIONS AND CONCLUSIONS}

The UWI Mona libraries play an active role in accessing and disseminating HIV/AIDS information. Their initiatives provide a good foundation for information learning, sharing and translation of information into knowledge and ultimately behaviour. Given the acknowledged importance of information access, dissemination and application to the fight against the HIV/AIDS pandemic, these are laudable initiatives. They also evidence a proactive and a socially relevant approach by the Mona libraries. Even so, there is still room for improvement. Notably, while the use of the LC system allows for reliable access to HIV/AIDS information, it would be useful for West Indian librarians to develop additional classes to facilitate the depth and breadth of the scope of the area of HIV/AIDS, especially as it relates to the West Indies. There is also the need for collaboration between the UWI Mona libraries and UWI HIV/AIDS Response Programme (UWI HARP) and also with UWI Mona's HIV/AIDS Implementation Strategies Committee. Together, these bodies could partner on mounting exhibitions, re-packaging information, especially information with a West Indian focus, hosting HIV/AIDS training programmes for staff and users, and establishing an HIV/AIDS academic library network.

\section{REFERENCES}

1. Albright K, Kawooya D. Libraries in the time of AIDS: African perspectives and recommendations for a revised model of LIS education. Int Info Lib Rev 2007; 39: 109-20.

2. Ghosh M. Role of Indian public libraries to increase the awareness of the community on HIV/AIDS. Int Info Lib Rev 2006; 38: 56-63.

3. Dube L. Insights into the diffusion of HIV/AIDS information in higher education institutions in South Africa. Int Info Lib Rev 2005; 37: 315 27. 
4. UNAIDS. Young people and HIV/AIDS. UNAIDS briefing paper Geneva: UNAIDS; 1999.

5. Gilmour JA. Reducing disparities in the access and use of Internet health information. A discussion paper. Int J Nurs Stud 2007; 44: 1270 8.

6. Furrie B. Understanding MARC bibliographic: machine readable cataloguing. $7^{\text {th }}$ ed. Washington DC: Library of Congress; 2003.

7. Griffiths JR, Brophy P. Student searching behavior and the web: use of academic resources and Google. Lib Trends 2005; 53: 539-54.
8. Fast KV, Campbell GD. "I still like Google": university student perceptions of searching OPACs and the web. Proc Am Soc Inf Sci Tech 2004; 41: 138-46.

9. Salisbury L, Laincz J, Smith JJ. Students' preferences in selecting information resources used to find scholarly information: a comparative study between undergraduate and graduate students. J Agri Food Info 2012; 13: 250-66.

10. Coombs KA. Lessons learned from analyzing library database usage data. Lib Hi Tech 2005; 23: 598-609. 